Saudi Journal of Engineering and Technology

Abbreviated Key Title: Saudi J Eng Technol ISSN 2415-6272 (Print) |ISSN 2415-6264 (Online)

Scholars Middle East Publishers, Dubai, United Arab Emirates Journal homepage: $\mathrm{http}: / /$ scholarsmepub.com/sjet/

Original Research Article

\title{
Santos Dumont Airport: Civil Aviation in Rio de Janeiro, Brazil
}

Dr. Murillo de Oliveira Dias*

Coordinator and Professor- Fundação Getulio Vargas, Brazil

\author{
DOI: $10.36348 /$ SJEAT.2019.v04i10.004 \\ | Received: 12.10 .2019 | Accepted: 19.10.2019 | Published: 25.10 .2019 \\ *Corresponding author: Murillo De Oliveira Dias
}

\section{Abstract}

In 2019, Santos Dumont Airport (SDU) completed 83 years of existence. The first civil transportation airport in Brazil was inaugurated on November 1936, while Rio de Janeiro was the Brazilian capital, two kilometers from the downtown area. To date, 29 thousand passengers are transported per day, approximately ten million per year, the second in public transportation in Rio de Janeiro, and the sixth Brazilian airport. On September 2019, SDU airport re-opened the two airport runways, closed for maintenance since August 12. Key findings pointed SDU airport important for regional flights in Rio, where Galeão International Airport (GIG) operates international flights. Also, despite the Brazilian capital has been changed from Rio to Brasilia, in 1961, SDU Airport, nevertheless, kept increasing civil transportation rates, due to its strategical location, in front of Guanabara Bay. Analysis of civil aviation in Brazil and worldwide, and discussion complete the present article.

Keywords: Aviation, Civil transportation, Brazilian, Airport.

Copyright @ 2019: This is an open-access article distributed under the terms of the Creative Commons Attribution license which permits unrestricted use, distribution, and reproduction in any medium for non-commercial use (NonCommercial, or CC-BY-NC) provided the original author and source are credited.

\section{INTRODUCTION}

This article investigated the Brazilian civil aviation for passenger's transportation, a descriptive single case study, which unit of analysis is the Santos Dumont Airport [1], located at the central area of Rio de Janeiro state, southeastern Brazil.

Airport, according to the Merriam Webster Dictionary is defined as "a place from which aircraft operate that usually has paved runways and maintenance facilities and often serves as a terminal" [2].

Santos Dumont airport, or hereafter just SDU according to the International Air Transport Association (IATA), which is the trade association for the airlines, worldwide sector representative, present in 117 countries [3], was founded on November 30, 1936, after two years of civil works, to be the first Brazilian civil aviation airport [4]. It was built in the Guanabara Bay embankment designed for this purpose, in a 370 thousand square meters area, using 2.7 million $\mathrm{m}^{3}$ of sand. Inaugurated with one $700 \mathrm{~m}$ runway, currently counts with two runways, from $1,323 \mathrm{~m}$ and $1,260 \mathrm{~m}$, respectively, with a single passenger terminal with $19,000 \mathrm{~m}^{2}$, with eight embark gates, two $\mathrm{km}$ from Rio de Janeiro central area [4].
Figure-1 depicts SDU airport view from the top, at the bottom of Guanabara Bay, within the central area.

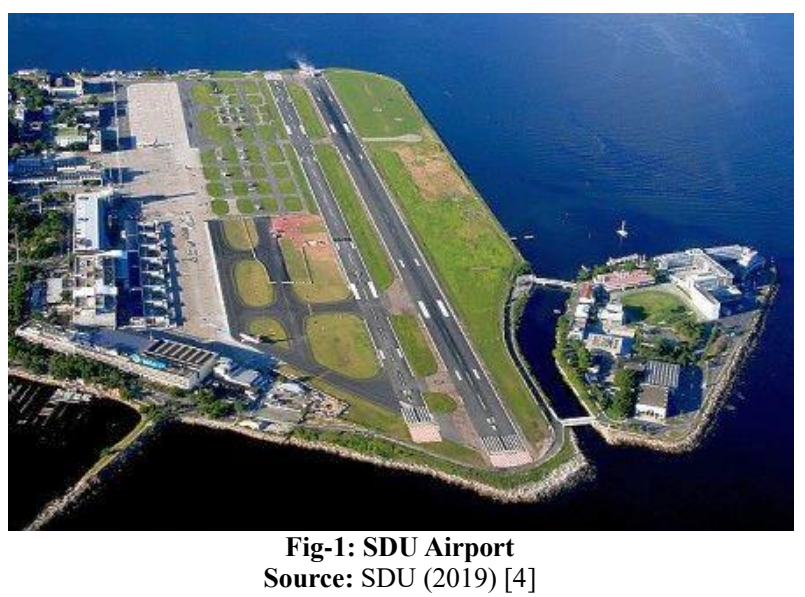

When SDU was inaugurated, Rio de Janeiro was the Republic's capital, therefore, the airport should be the most important one in Brazil. This situation changed when other bigger airports were built.

To date, SDU holds the sixth position regarding the number of passengers transported, as illustrated in the following Figure-2. 


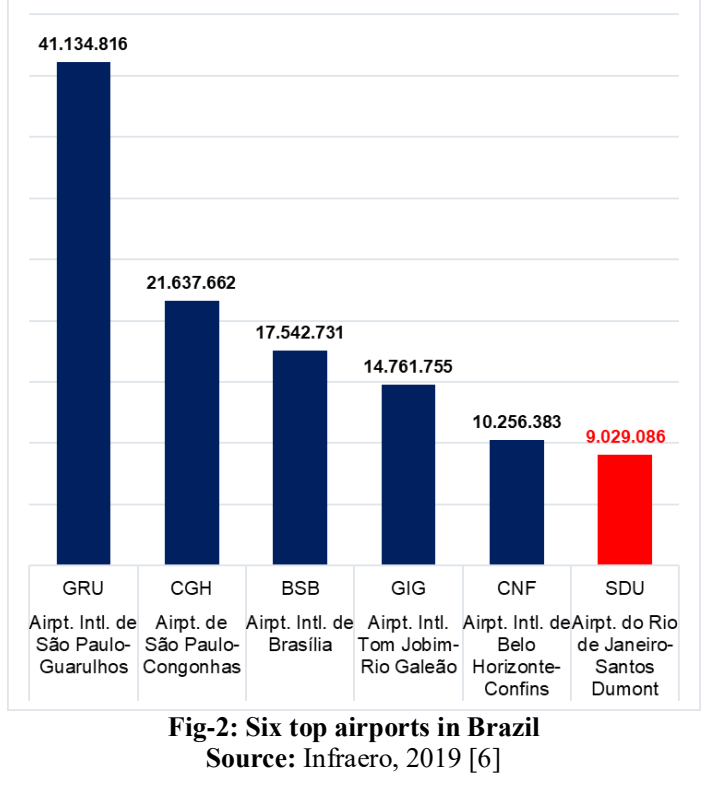

\begin{tabular}{|c|c|c|c|c|}
\hline$\#$ & Airport & Location & $\begin{array}{c}\text { Code } \\
\text { (IATA/CAO) }\end{array}$ & $\begin{array}{c}\text { Passangers per year } \\
\text { Total }\end{array}$ \\
\hline 1 & Atlanta Airport International & Atlanta, Georgia, Estados Unidos & ATL/KATL & 104171935 \\
\hline 2 & Beijing Airport International & Pequim, China & PEK/ZBAA & 94393454 \\
\hline 3 & Dubai Airport International & Dubai, Emirados Árabes Unidos & $\mathrm{DXB} / \mathrm{OMDB}$ & 83654250 \\
\hline 4 & Airport International de Los Angeles & Los Angeles, Estados Unidos & LAX/KLAX & 80921527 \\
\hline 5 & Airport International Haneda & Tóquio, Japão & HND/RJTT & 79699762 \\
\hline 6 & O'Hare Airport International & Chicago, Estados Unidos & ORD/KORD & 78327479 \\
\hline 7 & Heathrow Airport International & Hillingdon, Reino Unido & LHR/EGLL & 75715474 \\
\hline 8 & Hong Kong Airport International & Hong Kong, China & HKG/VHHH & 70314462 \\
\hline 9 & Pudong Airport International & Xangai, China & PVG/ZSPD & 66002414 \\
\hline 10 & Charles de Gaulle Airport International & Ilha de França, França & CDG/LFPG & 65933145 \\
\hline
\end{tabular}

Fig-3: Passenger transport worldwide

Source: IATA (2019) [3]

Currently, the principal activity of the SDU Airport is to operate the Ponte Aérea (air-bridge) Rio-São Paulo, which transported nearly four million passengers in 2018 [3].

In this article the importance of SDU to the Brazilian economy and history has been examined, after 83 years of existence.

\section{METHODS AND LIMITATIONS}

This article is compiled of multiple methods, including descriptive, single case study, in which unit of analysis is the SDU Airport in Rio de Janeiro, Brazil [1]. It is a qualitative research, inductive reasoning, interpretive, cross sectional study.

This research is limited to passenger transportation. Cargo transportation and other activities such as shopping center, and parking lot administration (SDU operates a parking lot for 1,110 cars) are not investigated in the present study [4].
This research is also limited to the Brazilian civil aviation legislation and the IATA's international standards [3].

\section{CIVIL AVIATION WORLDWIDE}

Figure-3 illustrates Civil transportation worldwide. While SDU transported approximately 9,029,086 passengers in 2018, the Atlanta Intl. Airport (IATA: ATL) has transported in the same period, 11.5 times the number of passengers carried out by SDU, near $104,171,935$ passengers. While Rio de Janeiro has 6.32 million inhabitants, Atlanta in the Midwest United States has approximately 450 thousand inhabitants [5].

Note in Figure-3 that Guarulhos Intl. Airport (GRU) has the largest operation in civil transportation within Brazil, with 41,134,816 passengers transported in 2018 .

Observe also in Figure 2 that after the Brazilian capital moved from Rio de Janeiro to Brasília in 1961, and since the BSB Intl. Airport was created, BSB transported in 2018 17, 542,731 passengers - 
almost two times more passengers than SDU within the same period (94.7 percent).

\section{BACKGROUND}

SDU was founded in 1936, in the President Getulio Vargas Administration (1930-1945), which airport name was given to honor the self-propelled airplane inventor, the Brazilian Alberto Santos Dumont. The project was designed by the French Architect Alfred Hubert Donat Agache, idealized the construction for the center of the Brazilian capital [4]. The passenger's terminal, however, was built and inaugurated two years later, in 1938. The airport runway was extended from the original $700 \mathrm{~m}$ to 1,050 $\mathrm{m}$ in 1938, since both economically (tourism) and politically (federal capital), Rio de Janeiro was the most important city in Brazil at that time.

After the end of the WWII, the SDU runway was extended to the current $1,350 \mathrm{~m}$. In 1947 , the international flights were transferred to Galeão Airport, due to a higher airport structure and extended runway [4]. SDU to date is a regional flight airport, in which Rio-São Paulo air-bridge - inaugurated in 1959 - is responsible nearly for 50 percent of the passengers transported [4]. In 1973, SDU started being operated by the Government Company Infraero [6].

After the capital transfer to Brasilia, in 1961, SDU slowly decreased in importance for the Brazilian civil aviation. In Figure-2, observe that BSB (Brasilia) airport holds the third position in passenger transportation, while SDU holds the sixth position [6].

On February 13, 1998, SDU airport was partially destroyed by an 8-hour fire. The fire started at 1:30 AM, without fatal victims. By the morning, the fire was completely extinguished, as depicted in Figure-4, as follows:

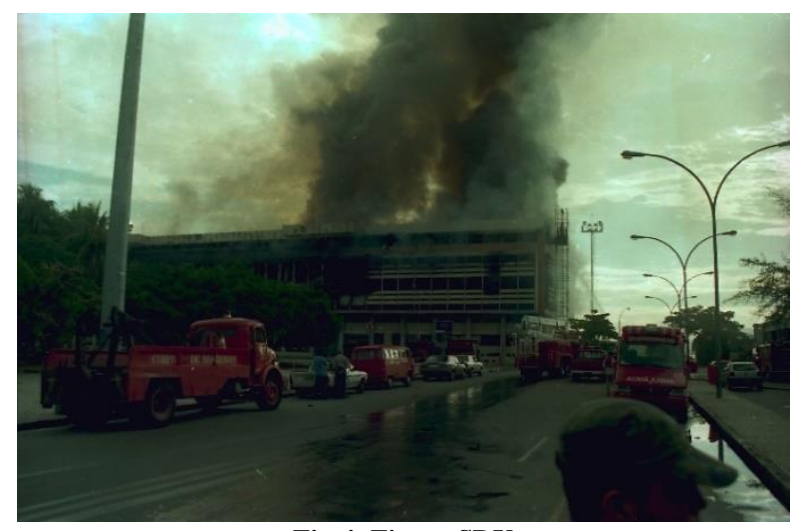

Fig-4: Fire at SDU

Source: SDU, 1998 [4]

SDU reopened for operations five months later, on August 1998. In 2004, SDU expanded its activities and a new terminal was built. Three years later, on May 26, 2007, the modern 8-bridge boarding terminal was inaugurated [6]. SDU Airport operates in one area of $833,000 \mathrm{~m}^{2}$, with a capacity of 29 operations per hour [4]. On August 2019, SDU interrupted activities due to maintenance at the main runway. On September 21, 2019, SDU reopened for regional flights [6]. Figures-5 and 6 illustrate the terminal built in 2007:
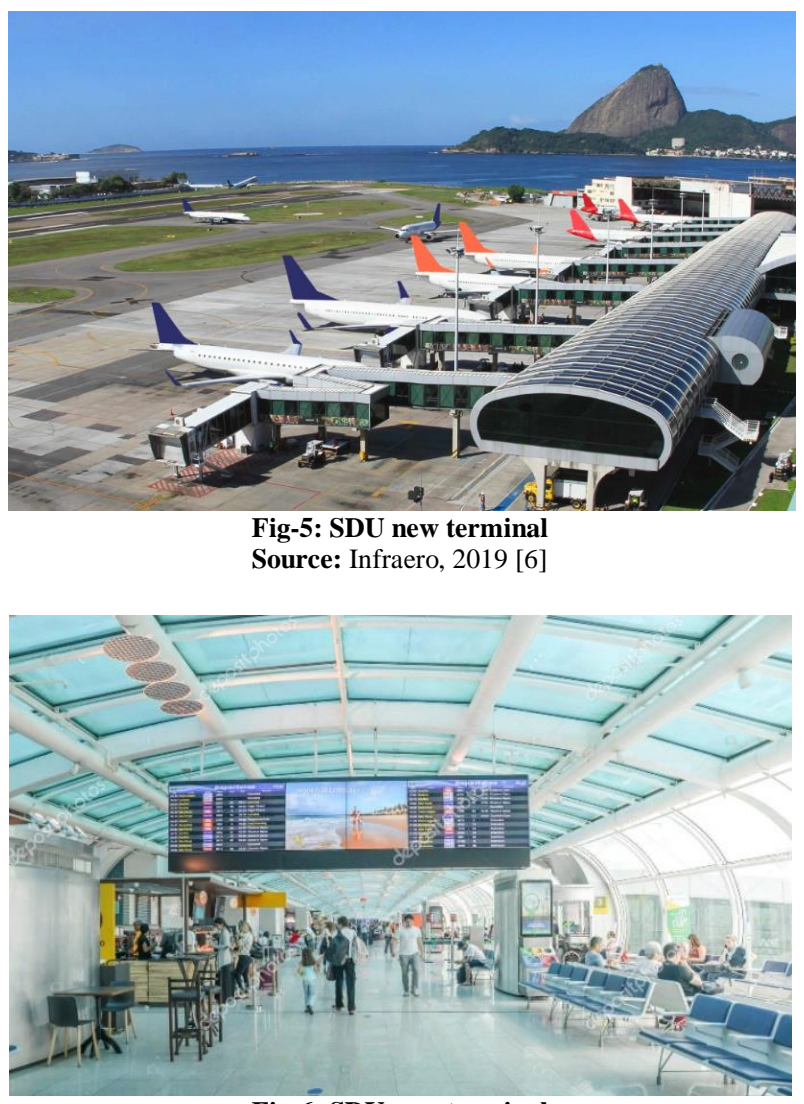

Fig-6: SDU new terminal

Source: Infraero, 2019 [6]

Observe in Figure-5 the new departure terminal, with the eight slots, along with the Guanabara Bay and the Sugar Loaf at the bottom. In Figure-6, note a modern and bold design, a new departure terminal was reopened on May 19, 2007. The project, designed by Sérgio Jardim, who designed the departure lounge, which is made of transparent green glass, allowing a complete view of Guanabara Bay, Rio-Niterói Bridge, and Sugar Loaf. Figure-7 depicts the two runways of SDU Airport:

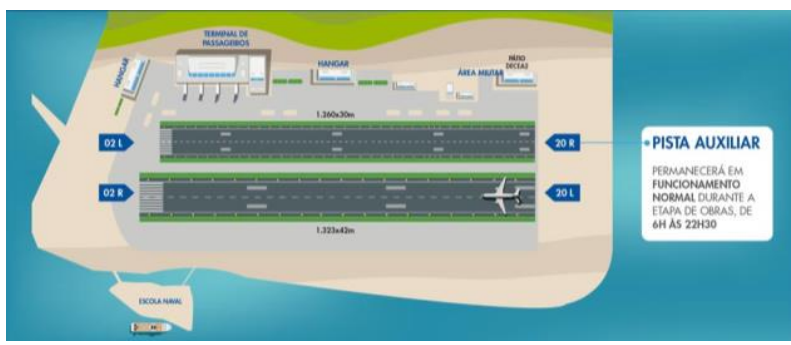

Fig-7: SDU runways

Source: Infraero, 2019 [6] 
Observe that the main runway was rebuilt, was the auxiliary runway remained operational, during the period of SDU's activities interruption [6].

In 2016, SDU was connected by Rail Light Vehicle (VLT Carioca), designed and built for the Olympics Rio 2016, connecting different modals of transportation within the Central area of Rio de Janeiro. For the first times, it was possible to go from the SDU airport to the intermunicipal bus station, port, metro, and other modal of transportation [7]. Note the SDU airport building at the left side of the picture [7].

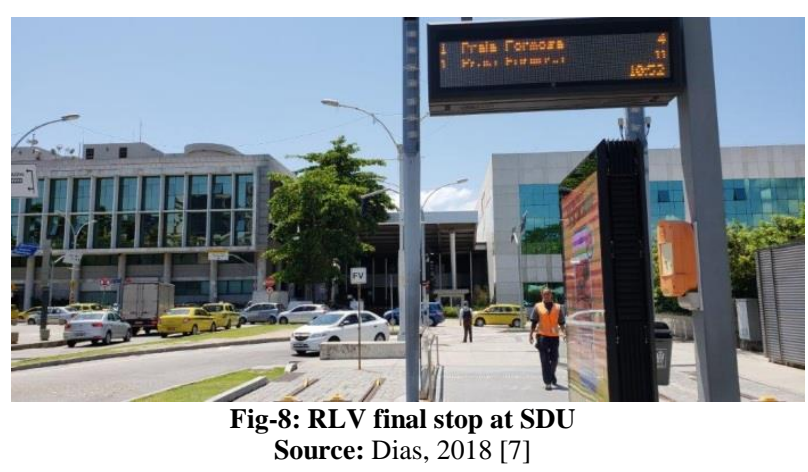

\section{DISCUSSION}

SDU Airport was built to be the international airport reference to the Brazilian Capital, Rio de Janeiro, in the first half of the XX Century. With the development of civil aviation in Brazil, other solutions should be devised, since SDU, due to its total extension, cannot be extended (See Figure-1), once it is surrounded by the Guanabara Bay. The solution was the construction of Galeão Airport, to date Tom Jobim International Airport [6]. Also, the civil aviation has grown in Brazil: São Paulo became the richest state in Brazil. Therefore, the wealthiest state shifted to São Paulo with the two most important airports: Guarulhos (GRU), and Congonhas (CGH) respectively, both transporting annually roughly 63 million passengers, against 23 million passengers transported by Rio de Janeiro's airports, Tom Jobim (GIG) and Santos Dumont (SDU), nearly one third passengers than São Paulo's airports. Finally, VLT Carioca (Rail Light Vehicle) filled an important gap on different modal transportation, connecting other modal transportation to the SDU Airport. While Tom Jobim International
Airport is distant $20 \mathrm{~km}$ from downtown, SDU is only two $\mathrm{km}$ away from the central and business area. Therefore, a sound alternative to the Rio de Janeiro population. SDU airport is also suitable to the tourism in the region: the Sugar Loaf, Museu do Amanhã, AquaRio, port, beaches such as Copacabana, Ipanema, and Leblon, the Christ Redeemer are now interconnected to SDU airport through VLT Carioca.

Future studies are encouraged to assess the impact of VLT Carioca on SDU airport passengers' traffic and vice versa, since its inauguration, in 2016. Also, research on multiple transportation modals are encouraged, to investigate the impact on the Rio de Janeiro Economy, as well as the Brazilian one in general, due to tourism industry increases since Olympics Rio 2016.

\section{REFERENCES}

1. Yin, R. (1988). Case Study Research: Design and Methods. Newbury Park, CA: Sage

2. Merriam Webster. (2019) "Airport". Retrieved from https://www.merriamwebster.com/dictionary/airport, on October 8, 2019. Limited, 1 edition.

3. IATA. (2019). Retrieved from https://www.iata.org/pages/airports.aspx, on October 8, 2019.

4. SDU. (2019). Histórico. Retrieved from https://www4.infraero.gov.br/aeroportos/aeroport o-do-rio-de-janeiro-santos-dumont/sobre-oaeroporto/historico/, on October 8, 2019.

5. IBGE. (2019). Rio de Janeiro. Retrieved from https://ibge.gov.br/, on October 8, 2019.

6. Infraero. (2019). Santos Dumont. Retrieved from http://www4.infraero.gov.br/imprensa/noticias/sa ntos-dumont-volta-a-receber-voos-neste-sabado21-9, on October 8, 2019.

7. Dias, M. D. O. (2018). Light Vehicle Vehicle in Rio de Janeiro: Alternative to Public Transportation in Brazil. Australian Journal of Science and Technology. 2(4), 187-193.

8. Dias, M. D. O., \& Teles, A. (2018). From Animal Traction to LRV: Public Rail Transportation in Rio de Janeiro. International Journal of Science and Research (IJSR) ISSN, 2319(7064), 765-770. 